DANMARKS GEOLOGISKE UNDERS ØGELSE · SERIE A · NR. 9 MILJØMINISTERIET · Geological Survey of Denmark

\title{
Middle Jurassic
}

deltaic and coastal

deposits in the Lulu-1 well of the Danish Central Trough

BY

NILS FRANDSEN

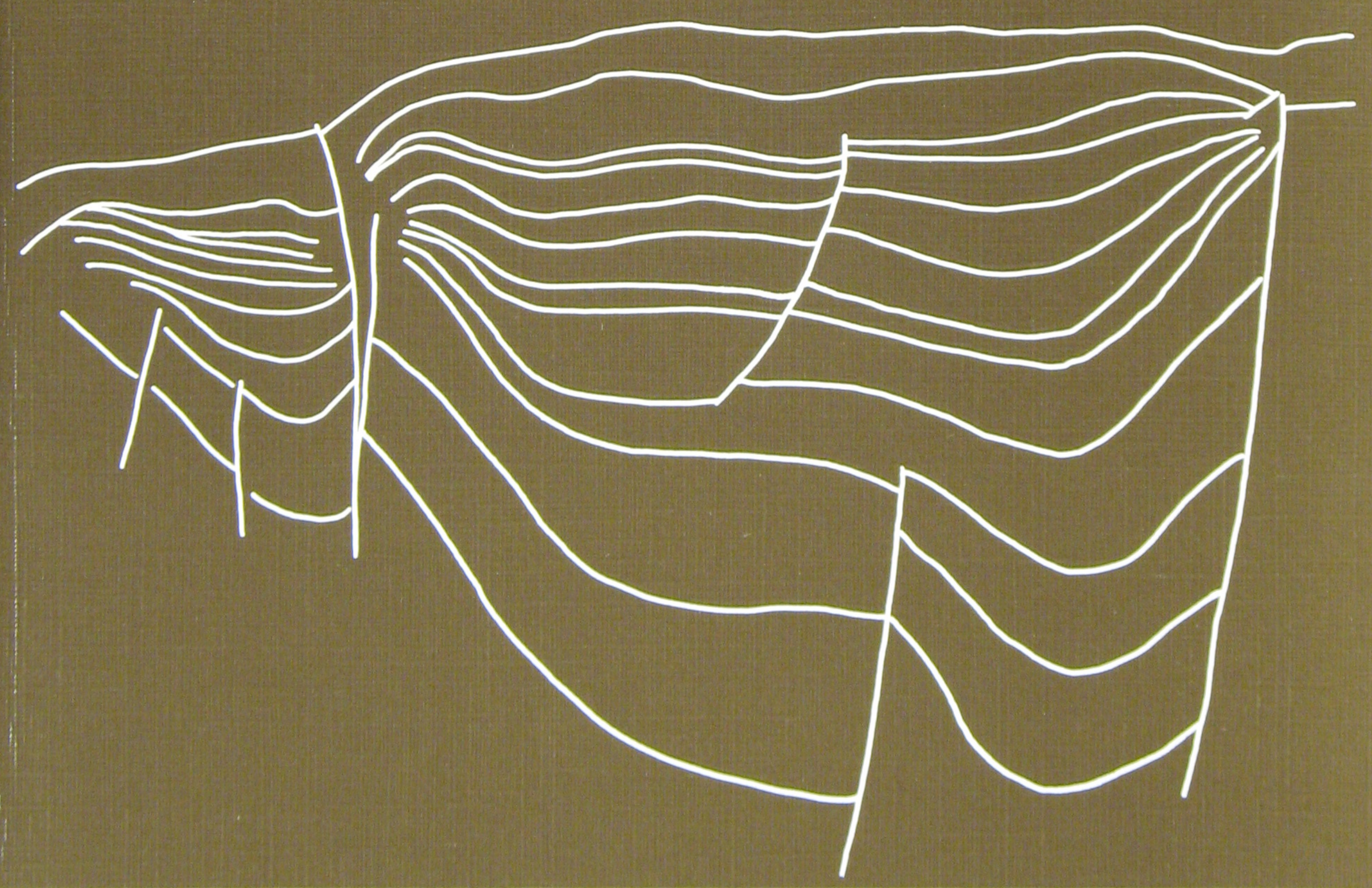

I kommission hos C. A. Reitzels forlag · København 1986 


\section{Middle Jurassic deltaic and coastal deposits in the Lulu-1 well of the Danish Central Trough}

BY

NILS FRANDSEN

I kommission hos C. A. Reitzels forlag · København 1986 


\section{A contribution to \\ EFP-83 project: \\ Jurassic-Lower Cretaceous stratigraphy and basin development of the Danish North Sea sector.}

Key-words:

North Sea, Denmark, Middle Jurassic, Cores,

Deltaic environment, Coastal environment.

with 3 plates

Vignette:

East-West section through the Tail End Graben

DGU Serie A nr. 9

ISBN 87-421-0741-5

ISSN 0901-0270

Oplag: 1200

Tryk: AiO Tryk as, Odense

Tegning: Helle Zetterwall

Dato: 1986-07-01

Nils Frandsen, nuværende adresse: Dopas

Agern Allé 24-26, 2970 Hørsholm

Redaktion: Leif Banke Rasmussen

(C) Danmarks Geologiske Unders $ø$ gelse,

Thoravej 31, DK-2400 København NV 


\section{Preface}

The present paper is one of several reports issued as the result of a research project carried out by the Geological Survey of Denmark in cooperation with the Geological Institute at the University of Copenhagen. The project has been financed by special contributions given by the Ministry of Energy for the period 1st of August 1983 to 31st of December 1985.

The project was entitled "Jurassic - Lower Cretaceous stratigraphy and basin development of the Danish North Sea sector". It has been decided to limit the study area to the Danish Central Trough, and furthermore the effort has been concentrated on the Middle Jurassic, the Upper Jurassic, and the Lower Cretaceous.

The scope of the project was to coordinate analyses of the stratigraphy, facies development and burial history in order to create a basis for predicting possible occurrences of reservoir rocks. The following reports (including the present one) will be printed in the series published by the Geological Survey of Denmark and issued in 1986 and 1987:

Frandsen, N.: Middle Jurassic deltaic and coastal deposits in the Lulu-1 well of the Danish Central Trough.
Heilmann-Clausen, C.: Lower Cretaceous dinoflagellate biostratigraphy in the Danish Central Trough.

Hoelstad, T.: Palynology and palynofacies analyses of the Middle Jurassic to Lower Cretaceous in the Danish Central Trough.

Hoelstad, T.: Palynology of the Middle Jurassic Lower Graben Sand Formation of the U-1 well, Danish Central Trough.

Jensen, T.F., Holm, L., Frandsen, N. \& Michelsen, O.: Jurassic - Lower Cretaceous lithostratigraphic nomenclature for the Danish Central Trough.

Møller, J.J.: Seismic structural mapping of the Middle and Upper Jurassic in the Danish Central Trough.

Poulsen, N.: Callovian (Jurassic) to Ryazanian (Cretaceous) dinoflagellate biostratigraphy of the Danish Central Trough.

Thomsen, E.: Lower Cretaceous nannofossil biostratigraphy in the Danish Central Trough.

Vejbæk, O.V.: Seismic stratigraphy of the Lower Cretaceous in the Danish Central Trough.

Vejbæk, O.V., Frandsen, N., Holm, L., Jensen, T.F., Møller, J.J. \& Michelsen, O.: Jurassic - Lower Cretaceous of the Danish Central Trough; - depositional environments, tectonism, and reservoirs.

DGU, 30th December 1985

Olaf Michelsen 


\section{Contents}

\begin{tabular}{|c|c|c|}
\hline Abstract . & 7 & Facies E, Heterolith. \\
\hline Introduction & 8 & Facies F, Mudstone . \\
\hline Facies descriptions and interpretations. . & 10 & Facies G, Coal \\
\hline Facies A, Parallel laminated, fine- to & 10 & Facies associations ... \\
\hline Facies B, Medium-grained sandstone with bio- & 10 & $\begin{array}{l}\text { Interdistributary Bay Association } \\
\text { Coastal Association ............ }\end{array}$ \\
\hline turbation and other deformations $\ldots \ldots \ldots$ & 12 & Conclusion and discussion \\
\hline Facies C, Parallel- to low angle cross-laminated & & Acknowledgements ... \\
\hline siltstone and fine-grained sandstone & 12 & References... \\
\hline
\end{tabular}

Facies D, Fine-grained, parallel- to small scale cross-laminated sandstone ............... 14 


\section{Abstract}

Four cores from the Middle Jurassic Bryne Formation of the Lulu-1 well in the northernmost part of the Danish Central Trough have been investigated. The cores were slabbed and a detailed description and facies analysis carried out. The cored sequence is very hetero- geneous and includes beds of sand-, silt-, claystone, and coal. Seven facies are defined and the sequence is interpreted as sediments of a deltaic interdistributary bay and associated environments overlain by sediments of a coastal environment. 


\section{Introduction}

The Lulu- 1 well is situated in the southern end of the Søgne Basin (fig. 1) and is placed on the crest of a N-S trending, faulted anticline formed as the result of salt uplift. The well was drilled in 1980 as a test for hydro-

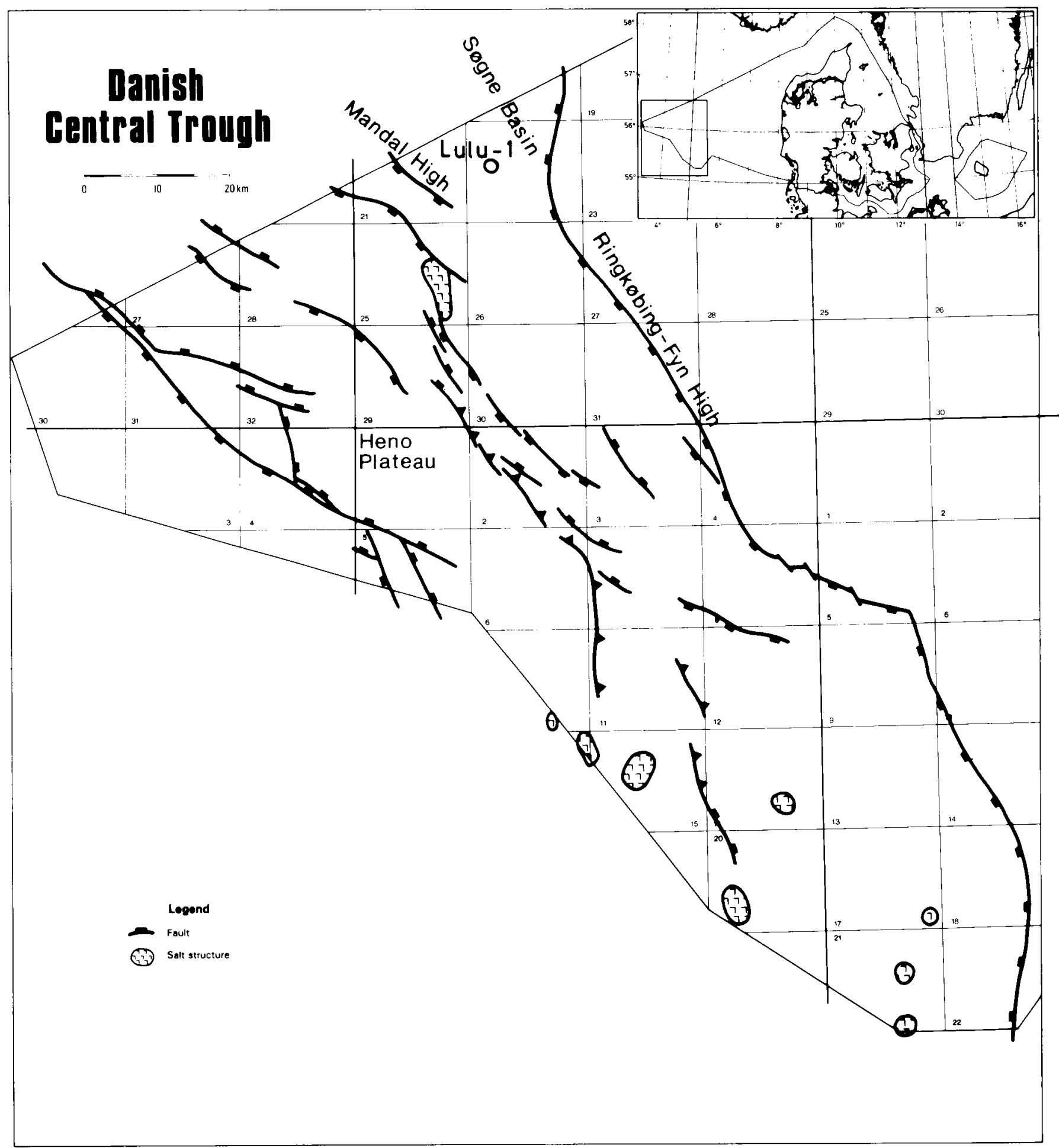

Fig. 1. Position of the Lulu-1 well. 
carbon accumulations in Maastrichtian-Danian chalk and had Middle Jurassic sands as a secondary objective.

The well bottomed in an evaporite sequence of assumed Permian or Triassic age. Directly overlying the evaporites is a $129 \mathrm{~m}$ thick sequence of interbedded sandstones, siltstones and claystones with scattered coal beds (fig. 2). The sequence has an overall dip of 8 $17^{\circ}$ caused by local tectonics. It is of Bathonian-Callovian and questionable Bajocian age as shown with some uncertainty by investigations of spores, pollen and a few dinoflagellates (Hoelstad, in prep.). On the basis of lithology and age of this heterogeneous sequence it is included in the Bryne Formation (Jensen et al. 1986). It is overlain by dark grey to black claystone of the Lola Formation.

Four cores with $5.5 \mathrm{~cm}$ diameter (nos. 12-15, see fig. 2) were cut consecutively from a depth $3 \mathrm{~m}$ below the top of the Bryne Formation. They cover a total interval of $45 \mathrm{~m}$ with a recovery of $43 \mathrm{~m}$. The sedimentological investigations carried out on these cores is presented on the following pages. Parts of the conclusions drawn are based on information from a stratigraphic report from Paleoservices Ltd.

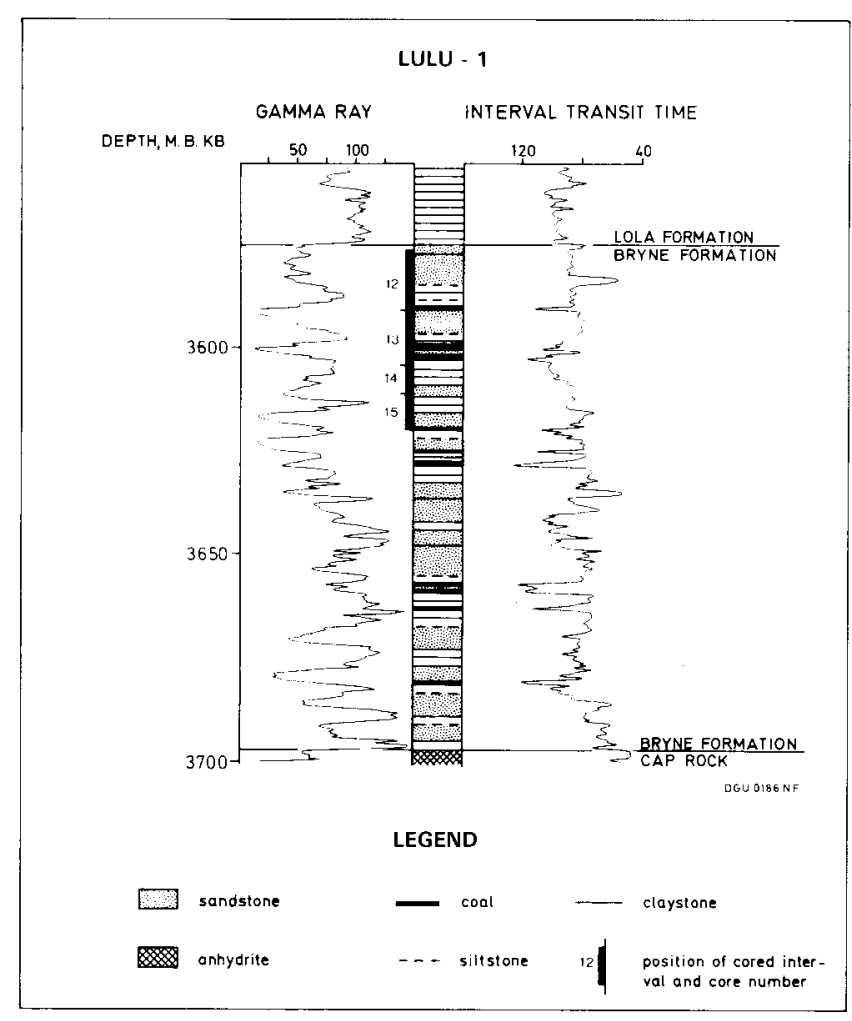

Fig. 2. Gamma and sonic logs and generalized lithology of the Bryne Formation in Lulu-1. 


\section{Facies descriptions and interpretations}

After plugging for porosity and permeability determinations, the cores were slabbed and detailed sedimentological descriptions and facies analysis were performed.

The facies show a very high degree of variation. The approach in the analysis has been to define as few facies as is consistent with showing the differences in depositional processes. Seven facies, labelled A-G, have been defined. The sedimentological log of the cored sequence shows the distribution and succession of facies (fig. 3). A number of facies sequences can be defined. The following paragraphs contain detailed descriptions and interpretations of the facies.

\section{Facies $A$ - Parallel laminated, fine- to medium-grained sandstone (PLATE 1)}

\section{Description}

This facies consists of fine- to medium-grained quartz sandstone grading to subarkose. It is moderately sorted in most cases. The grains are subangular to subrounded. Two intervals, one coincident with a rooted interval, contain scattered, whitish, rounded quartz grains 1-2 mm across (PLATE 1, fig. 2). The rock contains scattered mica. It is moderately hard to hard, and the cement is primarily silica, but very scattered patches of carbonate cement and of clay matrix occur.

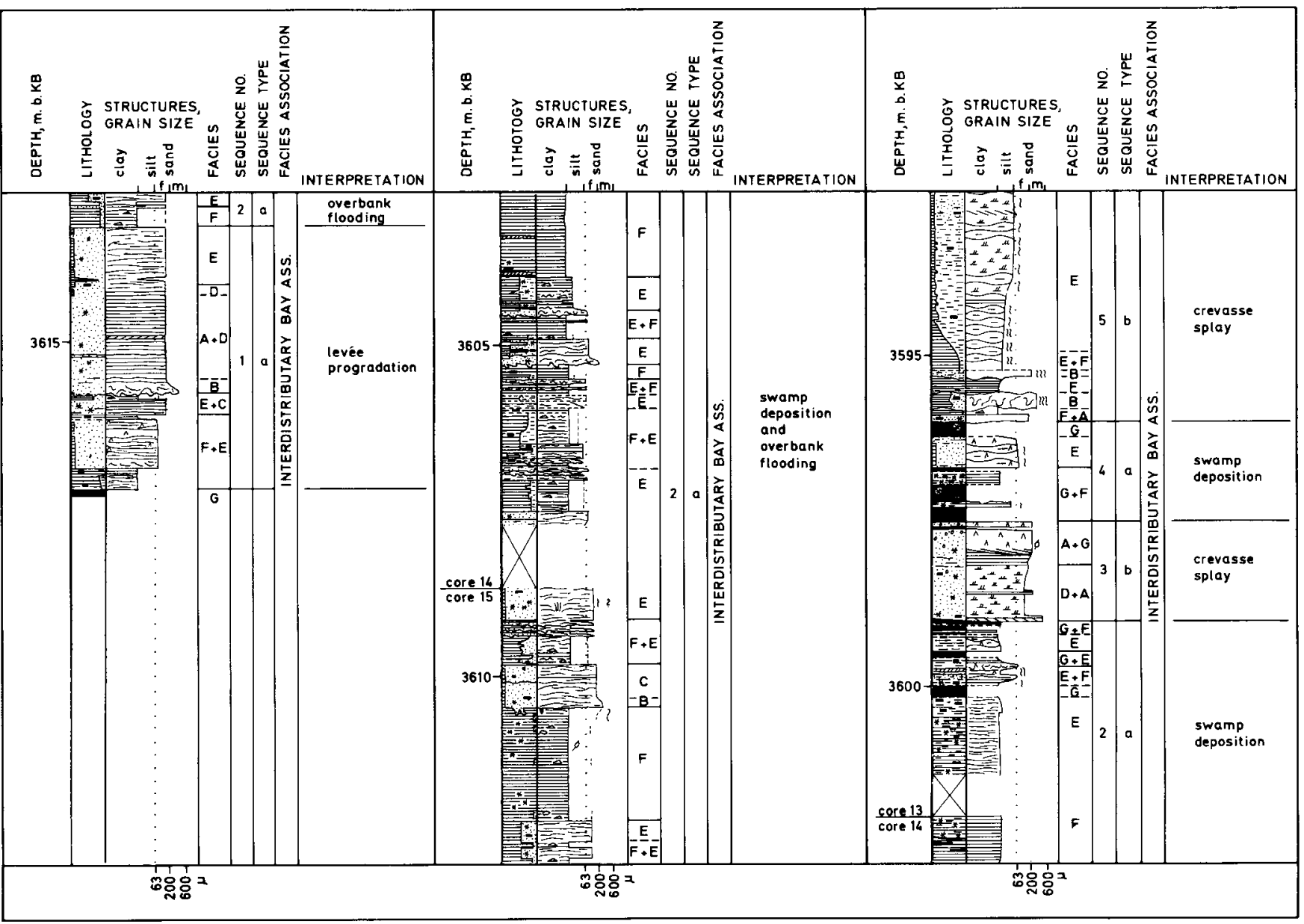

Fig. 3. Detailed lithologic log of the cored sequence of the Bryne Formation in Lulu-1. 
Porosities are fairly high due to the rather low degree of cementation. Scattered patches of black, residual oil occupy some pore space. Pyrite occurs as scattered, large concretions (up to several $\mathrm{cm}$ across) or more commonly as $\mathrm{mm}$-sized nodules. The abundance of coal particles varies from almost non-presence to abundant, finely disseminated microlignite or scattered laminae with a large content of microlignite. $\mathrm{Cm}$-sized coal pieces also occur. At two levels, the rock is heavily rooted below a coal bed (PLATE 1, fig, 2). The colour is mainly brownish grey, becoming darker grey in intervals rich in organic matter.

The most dominant structure is parallel, horizontal lamination, at places enhanced by thin clay laminae or laminae rich in microlignite. The lamination may be indistinct and at places it is slightly irregular. Some intervals appear structureless owing to a very low content of dark constituents and probably also owing to rather good sorting. A few cases of weak soft sediment deformation are seen and in the rooted intervals, the rootlets completely destroy the primary structure. Thin intervals of large scale cross-bedding occur, in two cases with erosional bases. The erosion has cut into parallel laminated facies A or into coal and claystone (facies G and F).

\section{Interpretation}

The large scale cross-beds with erosive bases are interpreted as scour-and-fill: Sudden pulses of turbulent water scoured into unconsolidated sediment. The subsequent infilling of the scours with cross-bedded sand caused a general levelling of the sediment surface and probably also a reduction of the water depth. Shallower water, smoother bottom topography and more or less unchanged flow velocity led to a gradual change to deposition under plane bed phase conditions as evidenced by the parallel lamination typical for facies A (Harms et al. 1982). Intermittent, thin intervals of large scale cross-bedding corresponding to the large ripple phase show that energy conditions fluctuated, probably in response to varying flow velocities.

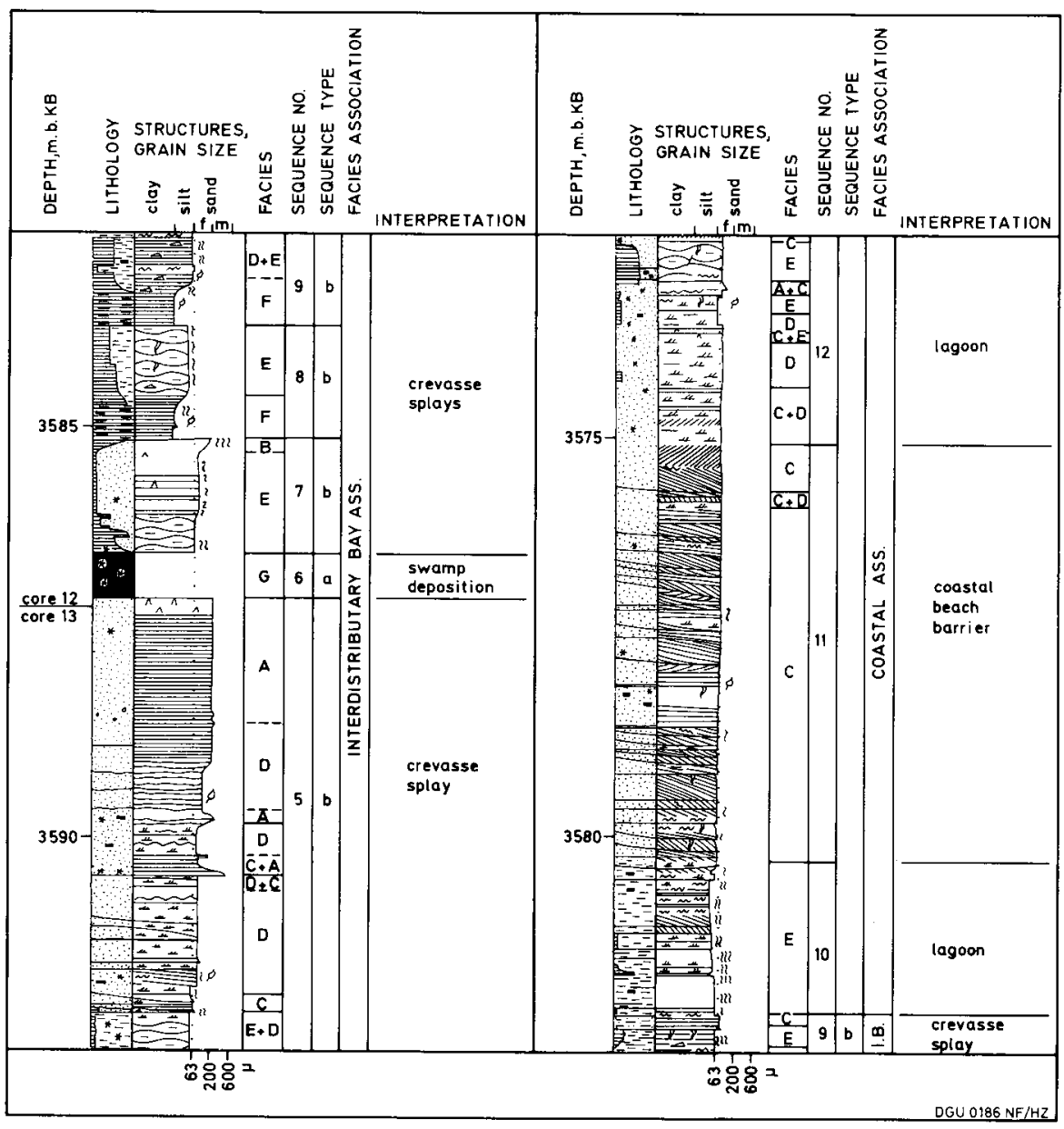

Explanations of symbols in fig. 3 .

\section{LITHOLOGY}

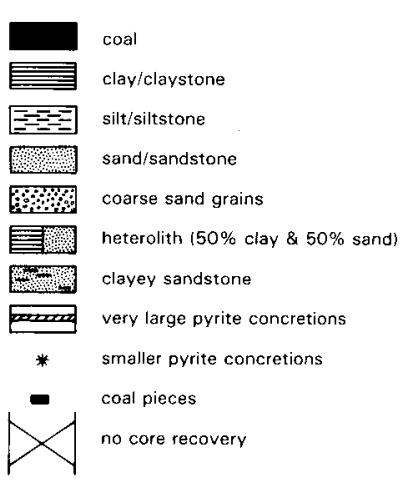

\section{STRUCTURES}

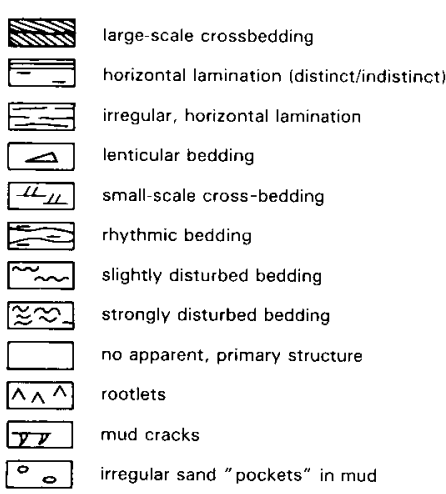

BED INTERFACES

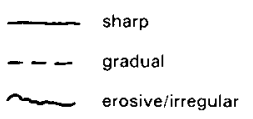

ADDITIONAL SIGNS

222 bioturbation (degree indicated

¿2 by 1 to 3 signs)

$\$$ plant fragments 


\section{Occurrence}

Facies A occurs as up to $1.5 \mathrm{~m}$ thick units mainly at top of sequences with upwards coarsening grain sizes or at the base of upwards fining intervals. It has a gradational relationship to sandstones of facies $\mathrm{D}$ and makes up $9 \%$ of the cored sequence.

\section{Facies B - Medium-grained sandstone with bioturbation and other deformations (PLATE 1).}

\section{Description}

Facies B comprises quartz sandstone that is mediumgrained grading to fine-grained in some cases. It is moderately to poorly sorted and has subangular to subrounded grains. Some intervals contain scattered, rounded quartz grains up to several $\mathrm{mm}$ across. The rock is moderately hard and non-calcareous. It contains scattered pyrite nodules and abundant mica. Microlignite is common. Scattered, cm-sized coal pieces occur. The colour is brownish grey with occasional yellowish shades.

The rock is strongly bioturbated, sometimes with single Teichichnus trace fossils clearly distinguishable (PLATE 1, fig. 4). In sequence 2 (fig. 3), a branching system of sand-filled tubes up to $1 \mathrm{~cm}$ wide protrudes from facies $B$ deeply into underlying mudstone of facies F. The tubes have no wall and no internal structure in the sand fill. The facies is also characterized by soft sediment deformation, among others a cm-wide claystone band penetrating the sandstone. The primary structures are thus almost completely destroyed but the facies appears to have been a sandstone-mudstone heterolith. In sequence 1 , the sandstone loads in "balland-pillow" fashion into an underlying heterolith of facies E.

\section{Interpretation}

Originally, facies B was deposited under rather calm but changing energy conditions as evidenced by the relict, heterolithic character of the rock. Some deformation structures are the result of slumping and indicate lateral movement of the sediment after deposition. Other structures like the claystone "band" mentioned above are caused by collapse of the sandstone probably during slump movement. The intense bioturbation and particularly the trace fossil Teichichnus suggest that the sediment was inhabited by deposit feeders. Thus, the sediment and the water above must have been well aerated. The tube system into facies $F$ is interpreted as the filling with sand of tubes left behind by decaying roots in facies $\mathrm{F}$.

\section{Occurrence}

Facies B is found as intervals up to $20 \mathrm{~cm}$ thick. It forms the basal bed of upwards fining sequences or the top bed of upwards coarsening trends. In one case the facies occurs as a sudden interval in mudstone of facies $\mathrm{F}$. Its total thickness corresponds to $2 \%$ of the cored sequence.

\section{Facies C - Parallel- to low angle cross- laminated siltstone and fine-grained sandstone (PLATE 2).}

\section{Description}

This facies is made up of coarse-grained siltstone to fine-grained quartz sandstone which is subarkosic and moderately to well sorted. It has subangular to subrounded grains. Mica and microlignite occur in varying amounts, most abundantly on bedding planes. Some intervals are heterolithic due to a content of clayey beds and to large amounts of mica and microlignite on bedding planes (PLATE 2, fig. 2). Larger coal fragments (some mm across) also occur. The rock is mainly silica cemented but scattered carbonate cement occurs and one interval is completely carbonate cemented so that the porosity is lost. Patches of clay matrix occur in varying abundance and the rock contains scattered, small pyrite concretions. The rock is brown with greyish and yellowish shades, medium grey in the carbonate cemented interval.

Parallel, horizontal lamination and low angle, planar, generally fairly large scale cross-lamination are the most common, primary sediment structures seen in facies C (PLATE 1, fig. 3 and PLATE 2, fig. 1). The crosslamination occurs as thin sets (few $\mathrm{cm}$ ), sometimes with reactivation surfaces. Generally, the angle between the lamination of a particular set and that of the neigh-

PLATE 1.

Fig. 1. Facies A. Fine-grained, slightly irregularly parallel laminated sandstone. Sequence 1, $3615 \mathrm{~m} \mathrm{b.KB}$.

Fig. 2. Facies A. Medium-grained, structureless sandstone with rootlets and scattered, coarse quartz grains. Overlain by facies G, coal. Top of sequence $3,3598 \mathrm{~m}$ b.KB.

Fig. 3. Facies C. Fine-grained, parallel laminated sandstone. Overlain by facies D, fine-grained, small scale cross-laminated sandstone. Facies D erosively overlain by facies A, medium-grained, parallel laminated sandstone. Sequence $5,3591 \mathrm{~m} \mathrm{b.KB}$.

Fig. 4. Facies F. Claystone. Overlain by facies B, medium-grained, bioturbated sandstone with Teichichnus trace fossils. Facies B loads into facies F. Gradual change upwards via facies $\mathrm{E}$, heterolith with fine-grained sandstone, to facies $\mathrm{F}$. Sequence $5,3595 \mathrm{~m}$ b. KB. 
PLATE 1
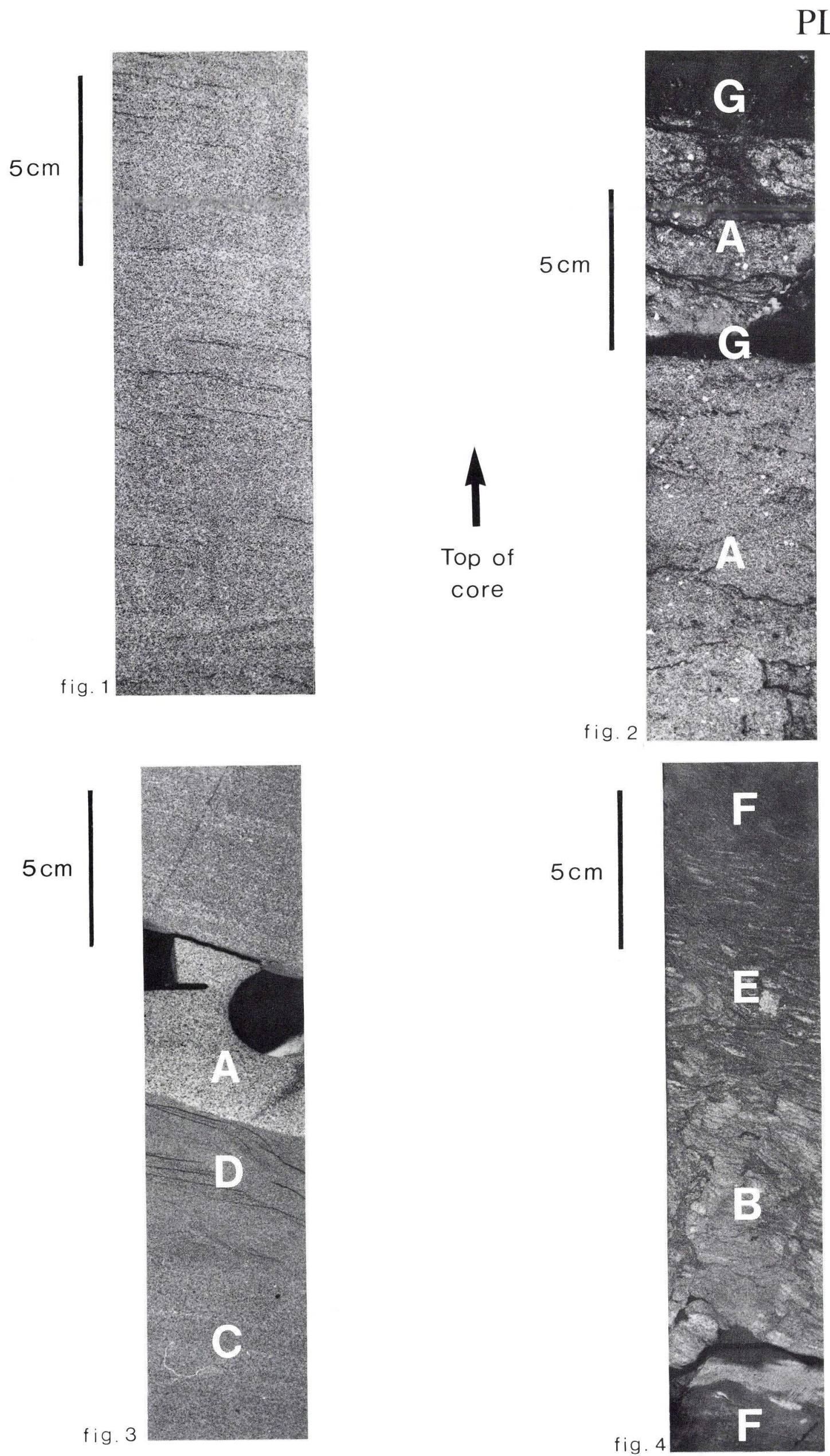
bouring set is small (less than $10^{\circ}$ ) but frequently the sets are cut erosively by sets at a greater angle $\left(15-20^{\circ}\right)$. Some small scour-and-fill structures occur. Erosion is also indicated by the truncation of some trace fossils. Soft sediment deformation, usually weakly developed, occurs in a few, thin intervals (few $\mathrm{cm}$ ). Some clayey beds show silt- and sand-filled cracks which may be desiccation cracks. Bioturbation is rare and occurs as cylindrical burrows 1-2 mm across, as rectilinear, vertical escape traces, or as large burrows looking like Teichichnus.

\section{Interpretation}

The generally low content of clay-sized particles, and the presence of escape traces suggesting rather rapid deposition, show that deposition took place under fairly high energy conditions, probably transitional from the small ripple phase to the upper plane bed phase (Harms et al. 1982). Sets bounded by erosion surfaces and characterized by parallel lamination and low angle cross-lamination with divergent dips in adjacent sets, are distinctive features of the swash-backwash zone (e.g. Thompson 1937), and the structure type depicted on PLATE 2, fig. 1 is reminiscent of the swash cross-stratification of Harms et al. (1982).

\section{Occurrence}

Facies $\mathrm{C}$ makes up one $4.5 \mathrm{~m}$ thick unit and several thin units generally occupying intermediate positions in upwards coarsening sequences and closely related to sandstones of facies D and heteroliths of facies E. All together, facies C comprises $15 \%$ of the cored sequence.

\section{Facies D - Fine-grained, parallel-to small scale cross-laminated sandstone (PLATE 2)}

\section{Description}

Lithologically, this facies is very close to facies C. Grain sizes are frequently coarser than in facies C (up to medium-grained) and rootlets are seen at one horizon. The rock is brown with greyish and yellowish shades.

The main difference to facies $\mathrm{C}$ is that the dominant structures are small scale cross-lamination grading to more or less irregular, parallel lamination (PLATE 2, fig. 3). Weak flaser lamination is developed at a few places with sufficient clay content. Minor erosion surfaces and some small scale soft sediment deformation structures are also seen. Teichichnus-like trace fossils occur very rarely.

\section{Interpretation}

The sedimentary structures indicate deposition in flowing water under small ripple phase conditions.

\section{Occurrence}

Facies D occurs as units up to $1.3 \mathrm{~m}$ thick and closely related to sandstones of facies $\mathrm{A}$ and $\mathrm{C}$. It makes up $12 \%$ of the cored sequence.

\section{Facies E - Heterolith (PLATES 2 and 3) \\ Description}

Facies $\mathrm{E}$ is mainly heteroliths consisting of laminae and thin beds of light-coloured siltstone and sandstone closely interbedded with dark claystone laminae. The relative abundance of the two components varies gradually from close to $100 \%$ siltstone and sandstone to about $90 \%$ claystone.

Lithologically, the most coarse-grained component is very close to facies $\mathrm{C}$. In some intervals it is mediumgrained. Some pyrite concretions are several $\mathrm{cm}$ across.

The fine-grained component is claystone that is silty at places and has a large content of microlignite and mica. It also contains mm-thick coal laminae.

The colour varies gradually from brown with greyish and yellowish shades in intervals rich in siltstone and sandstone to dark grey with brownish and greenish shades in those rich in claystone.

The structure changes between more or less irregular, parallel lamination and small scale cross-lamination, in some cases arranged in bundles (PLATE 2, fig. 4). Lenticular or wavy bedding is fairly common and small scour-and-fill structures occur. Some clay bands show silt- and sand-filled cracks like those mentioned under facies $\mathrm{C}$. Various small scale soft sediment

PLATE 2.

Fig. 1. Facies C. Fine-grained, large scale cross-laminated sandstone. Sequence 11, $3577 \mathrm{~m} \mathrm{b.KB.}$

Fig. 2. Facies C. Fine-grained, irregularly parallel laminated sandstone. Slightly heterolithic due to laminae rich in mica, microlignite and clay. Sequence $1,3616 \mathrm{~m}$ b.KB.

Fig. 3. Facies D. Fine-grained, small scale cross-laminated sandstone. Sequence 5, 3591 m b.KB.

Fig. 4. Facies E. Heterolithic siltstone with bundled laminae, one large trace fossil and several small ones. Sequence 5 , $3594 \mathrm{~m}$ b. KB.

Fig. 5. Soft sediment deformation in facies E, fine-grained, heterolithic sandstone. Sequence 1, $3616 \mathrm{~m} \mathrm{b.KB}$. 


\section{PLATE 2}
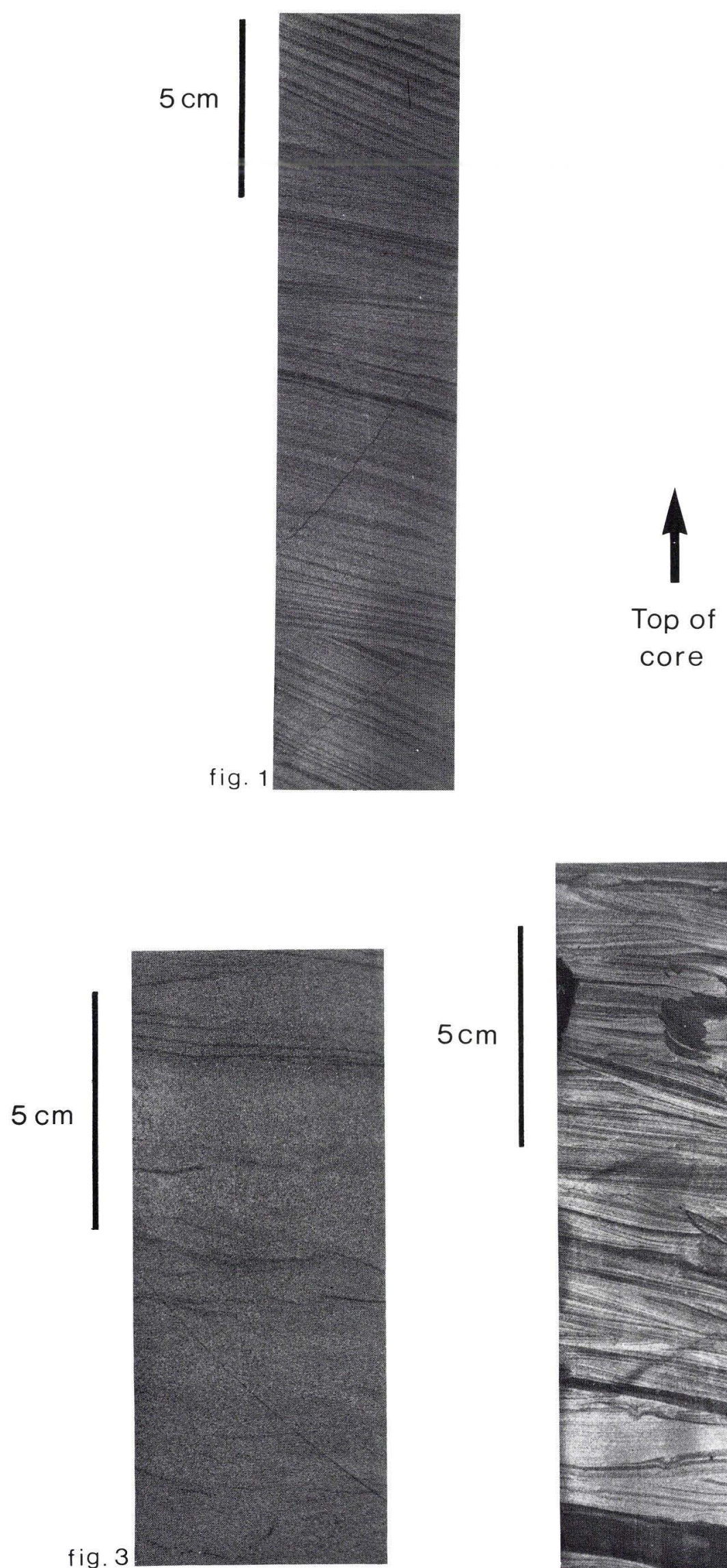
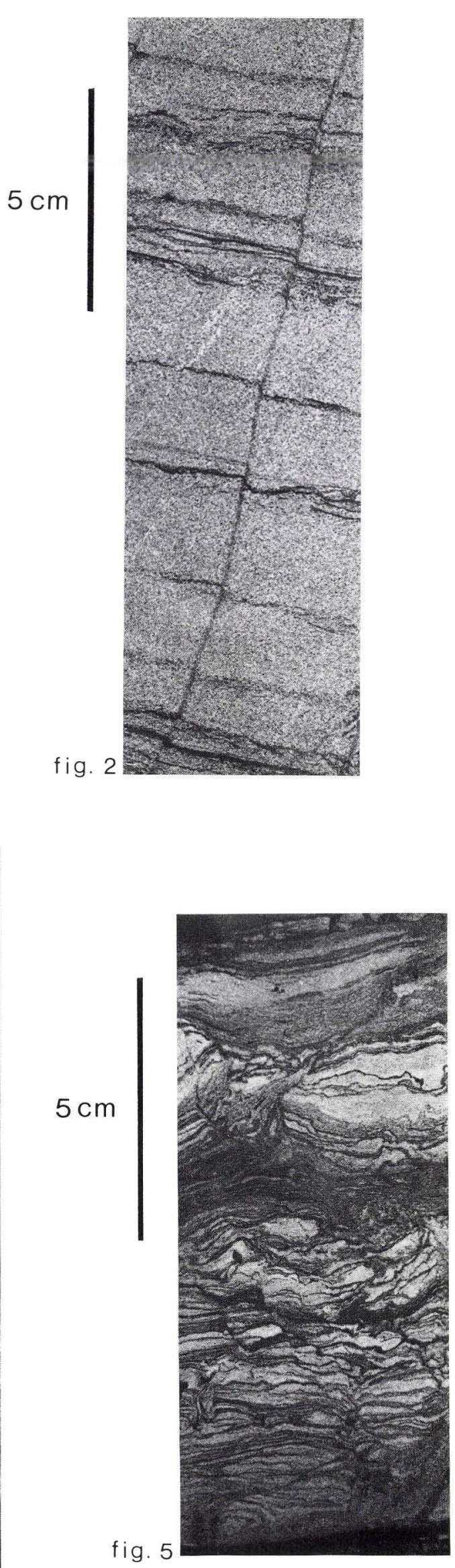

fig. 2

fig. 4

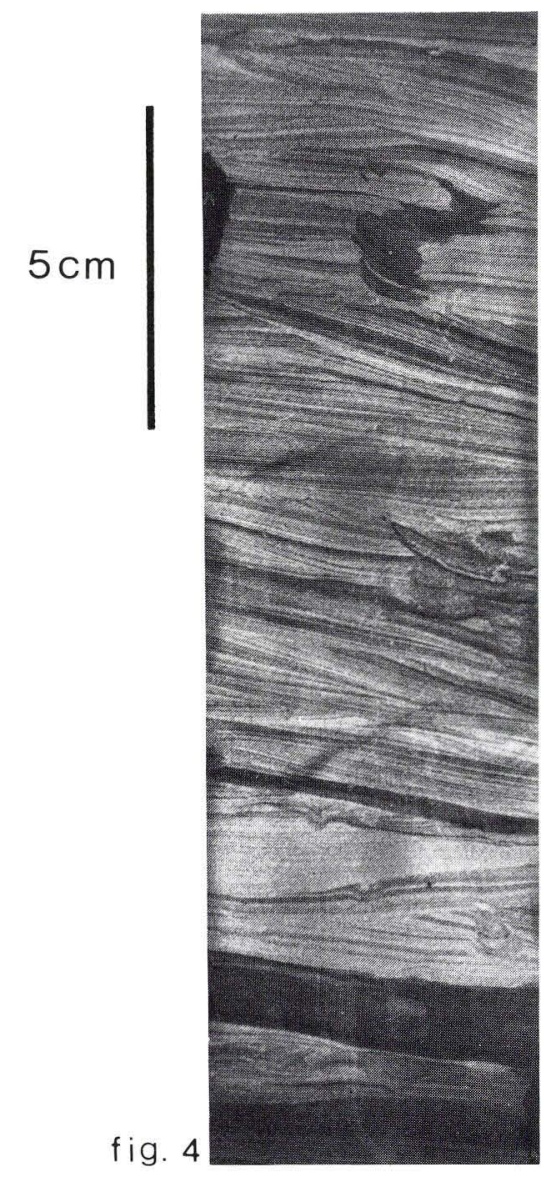


deformation structures occur (PLATE 2, fig. 5). Some are slump structures and some are possibly induced by water escape. Rootlets are common in several intervals (PLATE 3, fig. 1). The rooted intervals are generally overlain by coal. Some intervals are intensely bioturbated so that no primary structure is seen. In others, large Teichichnus burrows are clearly seen (PLATE 3, fig. 2). Small, Chondrites-like burrows, mm-thick, horizontal burrows and subvertical, irregularly winding burrows with diameter of $5 \mathrm{~mm}$ or more and with a light silt- and sand-fill (PLATE 3, fig. 3) occur at different levels.

Facies E forms the base of three small, upwards fining cycles in sequence 2 (fig. 3 and PLATE 3 , fig. 4). In these cases, the facies is fine-grained sandy, contains clay clasts more than $5 \mathrm{~mm}$ in size, and is characterized by a high degree of deformation. This type of facies $\mathrm{E}$ loads into underlying facies $\mathrm{E}$ or $\mathrm{F}$.

\section{Interpretation}

Facies $\mathrm{E}$ was deposited under changing energy conditions. The "coarse-grained" component was deposited by weak currents, under small ripple phase conditions as evidenced by the small scale cross-lamination (Harms et al. 1982). Small scour-and-fill structures indicate some erosive power of the currents. Wave influence is suggested by the occurrence of bundled laminae (de Raaf et al. 1977). Parallel lamination shows that some of the sediment settled out of suspension in very quiet water. This latter mechanism was solely responsible for the deposition of the muddy component of the facies. Low sedimentation rate is reflected by complete reworking of muddy sediment by bioturbation (only seen in sequence 10). The small, upwards fining cycles indicate repeated influence from relatively strong and quickly waning currents. The loading shows that deposition of sand took place shortly after deposition of clay before its consolidation. The sometimes very abundant bioturbation in facies $\mathrm{E}$ shows that the environment was well oxygenated. The recognizable trace fossils indicate that the animals responsible were deposit feeders digesting sediments rich in organic matter. The possible desiccation cracks indicate that there may have been periods of emergence. Low water depth is indicated by the presence of rootlets.

\section{Occurrence}

Facies $\mathrm{E}$ is the most common facies and makes up $40 \%$ of the cored sequence. The most common type of occurrence is interbedding with mudstones of facies $\mathrm{F}$.

\section{Facies F - Mudstone (PLATE 3)}

\section{Description}

Facies $\mathrm{F}$ is claystone with a varying silt content. In some cases it is slightly heterolithic. It is dark brown or dark grey grading to black and contains abundant mica, microlignite, larger plant and wood fragments and thin coal laminae. Dinoflagellates occur in facies F low in sequence 2 (fig. 3). The facies also contains abundant 1-2 $\mathrm{mm}$ pyrite nodules that are extremely abundant together with coal laminae in one $20 \mathrm{~cm}$ interval between coal beds in sequence 4 . Some very large pyrite concretions are related to coal laminae and pyrite is seen to replace wood in a few cases. The rock is hard to moderately hard and non- to slightly calcareous.

Most commonly, facies $\mathrm{F}$ is parallel laminated. Thin lenses and laminae of light-coloured siltstone or sandstone impart a heterolithic character to some intervals. In some cases, the rock is strongly bioturbated and the winding burrows described under facies $\mathrm{E}$ extend down into this facies (PLATE 3, fig. 3). In sequence 2, facies $\mathrm{F}$ is probably penetrated by a branching root system (see facies B).

\section{Interpretation}

The facies was deposited from suspension in calm water. Intermittent, weak currents caused deposition of thin siltstone and sandstone bands. Dinoflagellates show that at times the environment was under marine influence. Bioturbation in some intervals indicate a well aerated environment while abundant pyrite in others indicate reducing conditions during or soon after deposition. The reducing conditions were probably caused by decaying plant material as evidenced by the close relationship between coal and pyrite.

\section{Occurrence}

Gradational transitions between facies $\mathrm{F}$ and facies $\mathrm{E}$

PLATE 3.

Fig. 1. Strongly rooted facies E, fine-grained, heterolithic sandstone. Sequence 1, $3616 \mathrm{~m} \mathrm{b.KB}$.

Fig. 2. Large Teichichnus trace fossils in facies E, heterolithic siltstone. Sequence $5,3592 \mathrm{~m} \mathrm{b.KB}$.

Fig. 3. Facies F, claystone, upwards grading into facies E, clayey siltstone, with scattered rootlets. A system of large, irregularly winding burrows penetrates both facies. Sequence $2,3600 \mathrm{~m}$ b.KB.

Fig. 4. Facies F, claystone, abruptly overlain by facies E, irregularly bedded, fine-grained sandstone loading into facies $\mathrm{F}$ and upwards grading into ordinary facies $\mathrm{E}$, heterolith with fine-grained sandstone. Sequence $2,3605 \mathrm{~m} \mathrm{b.KB}$. 
PLATE 3
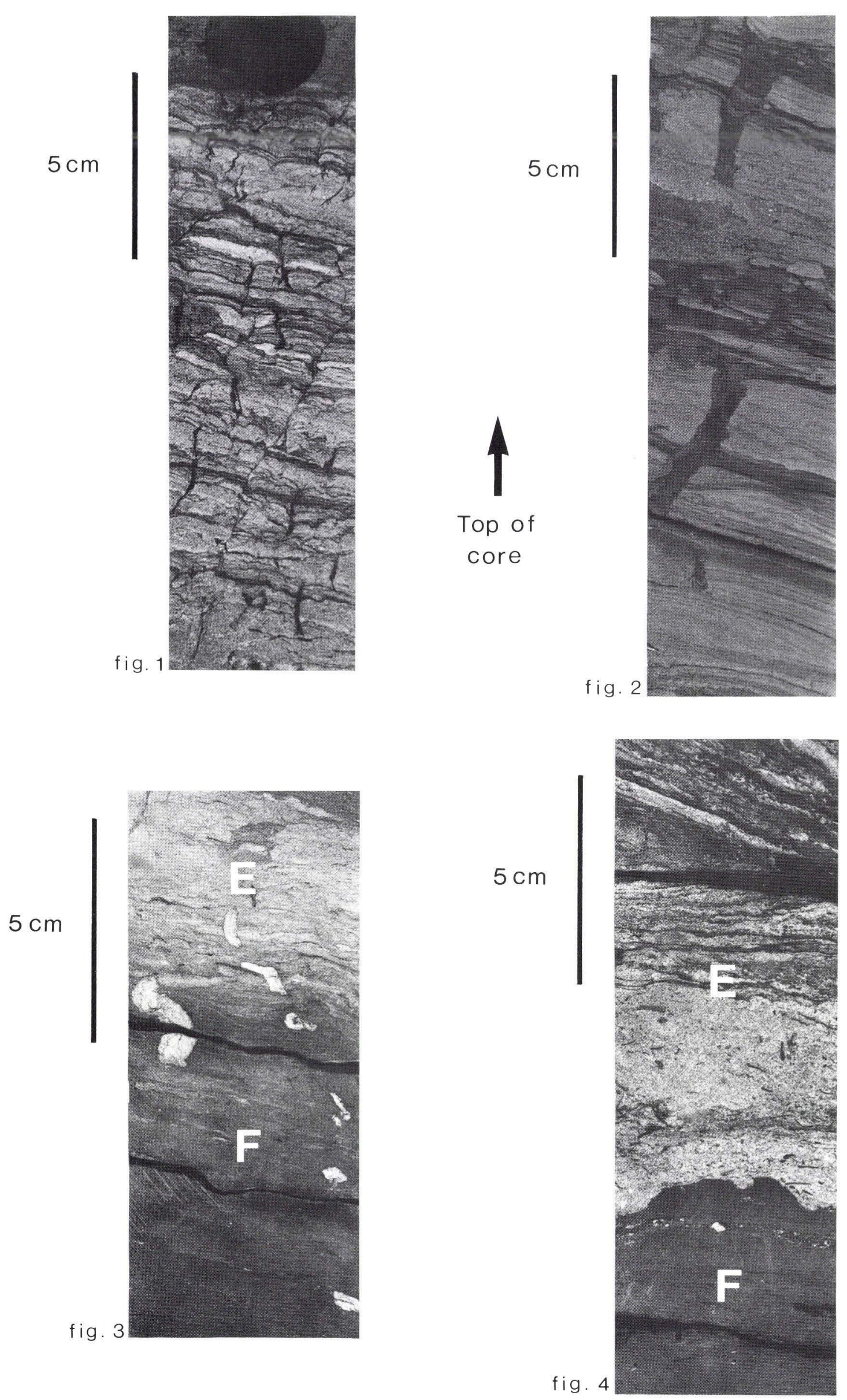
and $\mathrm{G}$ are common, and facies $\mathrm{F}$ is mostly related to these two facies. It makes up $18 \%$ of the cored sequence.

\section{Facies G - Coal. (PLATE 1)}

\section{Description}

This coal facies is made up of clarain usually with a high proportion of vitrain. It is varyingly pure with some clayey portions and thin lenses of fine-grained sandstone. The coals may contain large pyrite concretions and they have a black colour.

\section{Interpretation}

The humic character of the coal and the presence of rootlet horizons under the principal coal beds indicate that most of the coal is of autochthonous origin. Some very thin coal "beds" may actually represent large pieces of drifted wood rather than proper beds. The occurrence of thin sandstone lenses in the coals is evidence that pulses of sand-laden water intermittently flooded the areas of plant accumulation.

\section{Occurrence}

Facies $\mathrm{G}$ occurs directly above facies A sandstone with rootlets (PLATE 1, fig. 2), or it is interbedded with facies $\mathrm{E}$ and $\mathrm{F}$. The coring finished within a coal bed which, according to wireline logs, is approximately 60 $\mathrm{cm}$ thick. Facies $\mathrm{G}$ makes up $4 \%$ of the cored sequence. 


\section{Facies associations}

The facies described above are grouped into two facies associations, the Interdistributary Bay Association and the Coastal Association, occupying the lower three quarters and the upper one quarter of the cored sequence, respectively.

\section{Interdistributary Bay Association}

This association with a total thickness of $35.4 \mathrm{~m}$ comprises the facies sequences 1-9 (fig. 3). All seven facies are found in these sequences that fall in two types - a and $b$.

\section{Muddy sequences with coal and sandy or silty intercalations (type a)}

Sequences $1,2,4$ and 6 belong to this type. Generally, they are dominated by the muddy facies showing that deposition took place under low energy conditions. Rootlets, root casts and autochthonous coals further show that plant growth was possible at times, an indication of small water depth and low sedimentation rate. Numerous intercalations of silty and sandy sediments reflect interruptions in the low energy sedimentation. Most of these interbeds are thin and frequently they fine upwards. Loading and/or slumping in the basal portions of the interbeds are common features and show that sand and silt were deposited on unstable surfaces of unconsolidated mud.

\section{Upwards coarsening sequences (type b)}

Type b comprises the sequences 3,5 and 7-9. Their facies development shows a gradual change from relatively low depositional energy at the base to fairly high energy at the top. Thin beds of facies A at the base of or at intermediate levels in some of the sequences show that brief episodes of high energy sedimentation interrupted this general development. Cross-lamination and parallel lamination of plane bed phase origin reflect deposition from traction currents. Bundled laminae in various intervals may result from wave reworking. Exposure of sediment surfaces to the air is suggested by possible desiccation cracks. Bioturbation, at places very abundant, indicates a relatively low sedimentation rate, a well aerated environment and a rich fauna of deposit feeders. In sequence 5 the upwards increasing grain size is matched by a decreasing degree of bioturbation. Thus, the increasing energy level was paralleled by an increasing sedimentation rate. Two thin beds of facies $B$ close to the base of sequence 5 may result from a concentration of sand grains brought about by animals digesting the sediment (Coleman \& Prior 1982). The deformation of the lower facies $B$ bed has an element of slumping in addition to the bioturbation. "Floating", coarse sand grains in rooted facies A at the top of sequence 3 may be another example of biogenic reworking of the sediments: A bed of such sand was deposited as the uppermost bed of the sequence. The roots of the plants causing the formation of the overlying coal bed disrupted the sand bed and the constituent grains got mixed with the finer-grained sand below.

\section{Interpretation of the Interdistributary Bay Association}

Dinoflagellates at one level in sequence 2 are definite evidence of marine influence in the environment. Abundant pyrite in the coals of sequences 4 and 6 and particularly in one coaly interval of facies $F$ in sequence 4 may indicate some marine influence (Horne et al. 1978). Strongly bioturbated beds with Teichichnus also indicate some marine influence (Basan et al. 1978) but the bioturbation is not restricted to fully marine environments (Coleman \& Prior 1982). Plant growth giving rise to the formation of coal beds may be found in terrestrial environments or in environments with marine influence and close to the shore. Thus, the characteristics of the facies association described point to deposition in a regime transitional between terrestrial and marine conditions. The lower half of the sediments of this transitional environment (sequences 1 and 2) was deposited under low energy conditions with frequent episodes of abruptly increasing and gradually decreasing energy (type a sequences) whereas periods of gradually increasing and abruptly decreasing energy characterized the deposition of the upper half (type b sequences). As both types of deposition combined with plant growth can be found in different parts of a deltaic interdistributary bay, and as such a bay environment occupies an intermediate position between land and sea, the facies association described is termed the Inter- 
distributary Bay Association. According to this interpretation, the sequences of type a were deposited in a shallow bay relatively distant from delta distributaries. Some type of connection to the sea existed, at least intermittently. Frequent overbank floods from distributaries caused deposition of sandy and silty intercalations (Elliott 1974). In sequence 1 the uppermost, thick, upwards fining interval with evidence of rather high depositional energy suggests a period when a distributary was relatively close. In combination with an upwards coarsening trend in the lower part of sequence 1 this evidence shows that the sequence may be the result of progradation of the levee of a distributary channel (ibid.). The sequences of type b were deposited in crevasse splay lobes prograding into the bay and gradually filling it with sediment (ibid.).

\section{Coastal Association}

The facies sequences 10-12 (fig. 3) are included in this association that has a total thickness of $9.6 \mathrm{~m}$ and comprises facies $\mathrm{A}$ and $\mathrm{C}-\mathrm{E}$. The facies sequences are characterized by relatively constant grain sizes, and no subdivision into types is possible.

\section{Sequence 10}

This silty sequence is made up entirely by facies $\mathrm{E}$. It is bioturbated all through and primary structures are completely obliterated by bioturbation in the lower part whereas parallel lamination and small to larger scale cross-lamination stand out clearly in the upper part. There is a gradual transition to facies $\mathrm{C}$ of the overlying sequence.

The sequence was deposited in a low energy environment, and the bioturbation reflects a well aerated environment and a rather strong influence from the sea. Upwards decreasing intensity of bioturbation may be a response to increasing sedimentation rate.

\section{Sequence 11}

Sequence 11 is very fine-grained sandy and is made up by facies $C$ except for a thin interval of facies $D$. It is a sequence deposited under rather high energy conditions (large scale cross-lamination), high rate of deposition (almost no bioturbation, the presence of escape traces, no traces of plant growth) and frequently changing stream conditions (truncation of trace fossils, reactivation surfaces, scour-and-fill structures). How- ever, the presence of small scale cross-lamination (facies D) and a few thin clay laminae reflects periods of lower energy and even emergence may have taken place as indicated by possible desiccation cracks.

\section{Sequence 12}

This sequence is silty to very fine-grained sandy. The main constituent is facies $\mathrm{D}$ indicating an intermediate energy level during most of the deposition. However, intervals of facies $\mathrm{E}$ and facies $\mathrm{A}$ and $\mathrm{C}$, in some cases with slightly erosive base, are evidence of fluctuating energy levels. Low water depth and fairly low sedimentation rate during part of the deposition are indicated by rootlets in the upper part of the sequence which also may have evidence of emergence (possible desiccation cracks). Bundled lamination reflects wave reworking.

\section{Interpretation of the Coastal Association}

The interpretation is based on the interpretation of the underlying facies association, i.e.: The upper association was deposited in an environment closely related to but different from an interdistributary bay. The bioturbation in sequence 10 may reflect increased marine influence. Such an increase could be caused by a relative rise of sea level. In that case, coast deposits might be expected upwards in the sequence. Sequence 11 is interpreted as such coast deposits, the swash crossstratification (sensu Harms et al. 1982) of facies C indicating deposition in a beach environment (Thompson 1937). Thus, the facies association is termed the Coastal Association and sequence 10 is interpreted as the deposits of a coastal lagoon (Elliott $1978 \mathrm{~b}$ ). The small grain size suggests deposition at a relatively long distance from the open connection to the sea. Gradually, the environment changed to that of a beach (sequence 11) as a beach barrier migrated across the lagoon. Sequence 12 reflects a drop in depositional energy after deposition of the beach sediments. It was brought about by a slight change in relative position of the subenvironments of the lagoon-barrier complex, and the sequence is interpreted as lagoonal sediments from a part of the lagoon close to an inlet through the beach barrier. There was possibly some tidal influence as indicated by the cross-lamination and heterolithic aspects of facies $D$ and $E$. The occurrences of facies $A$ and $\mathrm{C}$ may result from minor wash-over episodes (Elliott 1978 b). 


\section{Discussion and conclusion}

The sequence of sedimentary rocks described above is interpreted as the deposits of a deltaic interdistributary bay complex overlain by coastal sediments. The sequence is found at the top of the Bryne Formation (fig . 2). Log and sediment characteristics of the remaining part of the formation show no significant difference from those of the interdistributary complex of the cored sequence. Thus, it is assumed that the interdistributary bay interpretation is valid for the whole formation apart from the coastal complex at the very top. Accordingly, the Bryne Formation in the Lulu-1 well reflects a transgressive development which is further evidenced by the fully marine claystones of the overlying Lola Formation. Vail \& Todd (1981) and Hallam (1978) suggest a global rise of sea level in the Early Callovian. Their interpretations are strongly supported by evidence of transgressions in the northern Viking Graben and further south in Britain and Germany. It is likely that the transgressive sequence described from the Lulu-1 well has an Early Callovian age (Hoelstad, in prep.). Thus, it appears that this sequence adds further North Sea evidence to the interpretations of an Early Callovian eustatic sea level rise.

Channel deposits might be expected in an interdistributary bay environment but none are recorded in the Lulu-1 core sequence. A combination of two factors may explain the lack of channel deposits. One is that in a delta, the area occupied by interdistributary bays is much larger than that occupied by river distributary channels. Thus, the chance of a well hitting a distributary channel at any one level in a complex of deltaic deposits is relatively small. The second factor of explanation extending the consequences of the first one vertically might be that the delta could be characterized by "bar finger sands", i.e. elongate sand bodies underlying the distributaries and showing that no major change of position of these took place during deposition of the delta sediment complex (Elliott 1978 a). This explanation implies that the delta was dominated by fluvial processes. Nothing speaks against such an interpretation.

Some sandstone units in the sequence show that they were deposited under rather high energy conditions. In consideration of such evidence, the sequence as a whole has a remarkable scarcity of coarser-grained sand. Fig. 1 shows that the Lulu-1 well is in fairly close proximity to the Ringkøbing-Fyn High. During the Middle Jurassic, this high and an area from the Mandal High towards the Heno Plateau possibly were emergent features (Gowers \& Sæbøe 1985) and either of them or both may have been source area for the Bryne Formation in Lulu-1. Before tectonic events at the end of the Early Jurassic (the Mid Cimmerian phase) these areas probably exposed Upper Palaeozoic and/or Triassic-Lower Jurassic sediments. Erosion in connection with the tectonic activity caused removal of a very large portion of these sediments. The Bryne Formation is the depositional product of this erosion and consequently it is most likely second cycle sediments at the least. The reworking thus assumed may explain the fine-grained character of the sediments.

Seismic evidence suggests a thickening of the Bryne Formation west of the Lulu-1 well (J.J. Møller, pers. comm.) and relatively large thicknesses are recorded to the north (e.g. $230 \mathrm{~m}$ in the Norwegian $3 / 5-2$ well). The fairly small thickness seen in Lulu-1 (129 m) may be due to synsedimentary movement of the salt underlying the formation. 


\section{Acknowledgements}

Finn Surlyk is thanked for critically reading an early version of the paper and for helpful suggestions. I had fruitful discussions with my colleagues Lise Holm, Jens Jørgen Møller and Lars Henrik Nielsen. Suggestions from Richard Bromley improved the English of the manuscript. Tove Nielsen and Irma Torres made the photographs, Helle Zetterwall did the drawing and Pia Andersen did the typing. All are thanked for their contributions. 


\section{References}

Basan, P., Chamberlain, C.K., Frey, R.W., Howard, J.D., Seilacher, A. \& Warme, J.E., 1978: Trace fossil concepts. SEPM Short Course 5, $201 \mathrm{pp}$.

Coleman, J.M. \& Prior, D.B., 1982: Deltaic environments of deposition. AAPG Mem. 31, pp. 139-178.

Elliott, T., 1974: Interdistributary bay sequences and their genesis. Sedimentology, 21, pp. 611-622.

Elliott, T., 1978 a: Deltas. In: Reading, H.G. (ed.): Sedimentary environments and facies. Blackwell Scientific Publications, pp. 97142.

Elliott, T., 1978 b: Clastic shorelines. In: Reading, H.G. (ed.): Sedimentary environments and facies. Blackwell Scientific Publications, pp. 143-177.

Gowers, M.B. \& Sæbøe, A., 1985: On the structural evolution of the Central Trough in the Norwegian and Danish sectors of the North Sea. Marine and Petroleum Geology, 2, pp. 298-318.

Hallam, A., 1978: Eustatic cycles in the Jurassic. Palaeogeography, Palaeoclimatology, Palaeoecology, 23, pp. 1-32.

Harms, J.C., Southard, J.B. \& Walker, R.G., 1982: Structures and sequences in clastic rocks. SEPM Short Course 9, 249 pp.
Hoelstad, T., (in prep.): Palynology and palynofacies analyses of the Middle Jurassic to Lower Cretaceous in the Danish Central Trough. Danm. geol. Unders., Ser. A.

Horne, J.C., Ferm, J.C., Caruccio, F.T. \& Baganz, B.P., 1978: Depositional models in coal exploration and mine planning in Appalachian region. AAPG Bull., 62/12, pp. 2379-2411.

Jensen, T.F., Holm, L., Frandsen, N. and Michelsen, O., 1986 (in press): Jurassic-Lower Cretaceous lithostratigraphic nomenclature for the Danish Central Trough. Danm. geol. Unders., Ser. A.

de Raaf, J.F.M., Boersma, J.R. \& van Gelder, A., 1977: Wave-generated structures and sequences from a shallow marine succession. Lower Carboniferous, County Cork, Ireland. Sedimentology, 24, pp. 451-483.

Thompson, W.O., 1937: Original structures of beaches, bars and dunes. Bull. Geol. Soc. Am., 48, pp. 723-752.

Vail, P.R. \& Todd, R.G., 1981: Northern North Sea Jurassic Unconformities, Chronostratigraphy and Sea-level Changes from Seismic Stratigraphy. In: Illing, L.V. \& Hobson, G.D. (eds.): Petroleum Geology of the Continental Shelf of North-west Europe, Inst. of Petroleum, London, pp. 216-235. 
This paper presents a sedimentological evaluation of a deltaic sequence 